\title{
Morphology and Ecological Characteristics of Paracyclops Novenarius Reid, 1987: A Cyclopoid Copepod Inhabiting a Highly Contaminated Aquifer in Central-North of Mexico
}

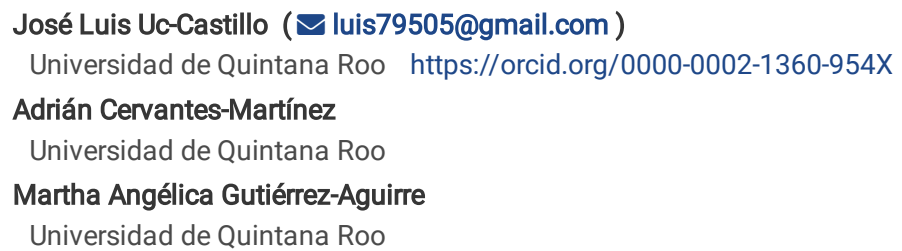

\section{Research Article}

Keywords: Arsenic, Cyclopoida, Ecological parameters, Mexico, Ontogeny, Water polluted

Posted Date: September 3rd, 2021

DOI: https://doi.org/10.21203/rs.3.rs-673354/v1

License: (c) (i) This work is licensed under a Creative Commons Attribution 4.0 International License. Read Full License 


\section{Abstract}

This work reports the freshwater copepod Paracyclops novenarius, in a water body with high arsenic concentrations. Morphologic analysis, abundances, body size of the copepod and physical and chemical variables of the water (including arsenic concentrations) were evaluated in two different climatic seasons (rainy and dry). Morphological analysis showed that the high arsenic concentrations do not affect the morphology of $P$. novenarius, including all its development and adult instars. The highest abundances of this species were found in the dry season for all development stages, with values of 1.51 and 1.50 , $4.46,0.21 \mathrm{ind} / \mathrm{L}^{-1}$, for nauplii, copepodites, females, and males, respectively. However, these values are lower than other aquatic systems of the region and the world, without polluting agents. The highest arsenic concentration was found in the dry season $\left(58 \mathrm{mg} / \mathrm{L}^{-1}\right)$ and the lowest during the rainy $\left(54.5 \mathrm{mg} / \mathrm{L}^{-1}\right)$. The body size of the analyzed organisms was larger in rainy compared to dry, with an average of $637.2 \pm 42 \mu \mathrm{m}$ for females and $650 \pm 37 \mu \mathrm{m}$ for males. A MannWhitney $U$ test showed significant differences in lengths by season and by arsenic concentration $(U=1284.5, U=1284.5 ; p<0.05)$. The results of this study could provide information for environmental impact assessments on aquatic systems.

\section{Introduction}

Arsenic (As) is a natural element present in the environment, including aquatic systems; however, in recent years, anthropogenic activities (e.g., mining, metallurgical processes, fossil fuel combustion, pesticide use) have caused an increase in average concentrations in epicontinental water bodies (Ravenscroft et al. 2009; Gutiérrez and Gagneten 2011). For example, in Matehuala, San Luis Potosi, Mexico, high concentrations of arsenic (up to $158 \mathrm{mg} / \mathrm{L}^{-1}$ ) have been reported due to metallurgical wastes (Razo et al. 2004; Martínez-Villegas et al. 2013; Ruiz-Huerta et al. 2017; Mendoza-Chávez et al. 2021), which would lead to significant alterations in physical-chemistry parameters and generate multiple impacts in the aquatic biodiversity (Moreira et al. 2016).

One of the critical components in the aquatic biodiversity to assess these impacts on water systems is zooplankton, and within this is the class Copepoda $\mathrm{H}$. Milne-Edwards, 1840, which contributes between 55-80\% of the zooplankton biomass (Kiørboe 1998; Ordóñez-López and Ornelas-Roa 2003). In the world, 14,000 species are known, of which 3000 are freshwater species (Suárez-Morales et al. 2020). Moreover, their high sensitivity to physical and chemical changes in the environment make them suitable for use as bioindicators of metal and metalloids contamination (Gutiérrez et al. 2010; Gutiérrez and Gagneten 2011; Gutiérrez et al. 2012; Villagran et al. 2019).

Therefore, its study turns essential to understand better the toxic process in longer-term, such as changes in morphology and population dynamics which acquires great relevance from an ecological and environmental perspective.

In this work, we performed a detailed analysis of morphology, and we evaluated some ecological characteristics of the copepod Paracyclops novenarius Reid, 1987 (initially reported as Paracyclops chiltoni Thomson, 1882 by Mendoza-Chávez et al. 2021) inhabiting water polluted by arsenic as well as physical and chemical variables of the water (including arsenic concentrations) in two different climatic seasons (rainy and dry).

\section{Material And Methods}

The study area is in the city of Matehuala, San Luis Potosi, Mexico and corresponds to a shallow water body ( $<2 \mathrm{~m}$ depth) known as "Club de Tiro", which is part of an artificial complex of water contaminated with arsenic (Razo et al. 2004; Martínez-Villegas et al. 2013) (Fig. 1). The climate is arid; its annual average temperature is $19.3^{\circ} \mathrm{C}$ with an average yearly rainfall of $450 \mathrm{~mm}$. The predominant soil type is calcic to gypsic xerosol with a gradual increment of gypsum towards the center (Razo et al. 2004; CEFIM 2016) (for more details of the study site, see Mendoza-Chávez et al. 2021).

Biological samples were collected in two different seasons registered by INEGI (2002) (rainy = July 2017 and dry = December 2017). All samples were collected with a plankton net of $50 \mu \mathrm{m}$ mesh by filtering a known volume and were fixed with $96 \%$ ethanol (Cervantes-Martínez and Gutiérrez-Aguirre, 2015).

To identify the species and some effect on the development of individuals due to the arsenic concentration, adult females and males collected (10 as a minimum of each collection) were analyzed with light microscopy Nikon Eclipse 50i and scanning microscopy JEOL-SM-6010. Some nauplii and copepodites were included in this analysis. Suárez-Morales et al. (2020) established the procedures for material preservation, preparation, and conservation; biological material is in the reference Collection of Zooplankton of ECOSUR at Chetumal (ECOCH-Z-10508).

Detailed morphology of prosomal and urosomal appendages along the development of the specimens was considered. The terminology for the armament of each appendage followed Huys and Boxshall (1991) and Karaytug and Boxshall (1999): antennule (= A1), antenna (= A2), mandible, maxillule, maxilla, maxilliped (= Md, Mxl, Mx, Mxp, respectively), first to sixth legs (= P1 to P6), Exp (= appendage, exopodal limb), Enp (= appendage, endopodal limb), setae on the first antennular male segment (setation elements $\mathrm{A}-\mathrm{H}$ ).

The abundance of individuals (individuals $/ \mathrm{L}^{-1}$ ) was estimated based on total counts performed with a stereoscopic microscope model Olympus SZ30. Body size $(\mu \mathrm{m})$ of adult specimens (the number depending on the availability) was obtained by measuring the distance from the head to the furcal ramus, using an optical microscope model Olympus CX21 with a graduated eyepiece (Belmonte et al. 2006). Sizes (both males and females) were compared in function to the season and arsenic concentration with a Mann-Whitney $U$ test. The sex ratio (F:M) was estimated by the relationship between the total number of females (F) and the total number of males (M) sexed (Dur et al. 2012).

In each sampling campaign, were measured in situ physical and chemical water variables: dissolved oxygen $\left(\mathrm{mg} / \mathrm{L}^{-1}\right)$, temperature $\left({ }^{\circ} \mathrm{C}\right)$, electrical conductivity $\left(\mu \mathrm{S} / \mathrm{cm}^{3}\right), \mathrm{pH}$, and salinity (PSU), using a multi-parameter model Hanna Instruments HI9829. 
Finally, determination of arsenic in the water samples collected was made using the "Method 200.7 Rev. 4.4: Determination of Metals and Trace Elements in Water and Waste by inductively Coupled Plasma-Atomic Emission Spectrometry" (EPA 1994). The analysis was carried out in the National Laboratory of Agricultural, Medical and Environmental Biotechnology (LANBAMA), of the Potosino Institute of Scientific and Technological Research A.C. (IPICYT). The statistical analysis and the graphics generated were performed in the software OriginPro 2016 V.9.3.

\section{Results}

Normal and stable development was observed along the different instars, different arsenic concentrations in the media, and different sampled dates between the analyzed specimens (Figs. 2-5). All naupliar stages with the typical Labrum, A1, A2, Md, and one couple of spinulose caudal seta on each side of the body were present in Nauplius II to VI (Fig. 2a-C). Antennule armed with sabre-shaped masticatory process; the maxillule is differentiated as on setose, distal lobe, and first leg bud is differentiated in Nauplius VI (Fig. 2a-c).

As typically, the outer lateral furcal seta (seta III) is placed more proximally during Copepodite I and lateral furcal seta (II) is placed inwards; whereas dorsal seta (VII) is placed near its final place when the copepodite grows to instar V (Fig. 2d-g, 3a, b). Six antennular segments, as well as the first P1-P3, were developed during CV (Fig. 3c-f).

For adults (Figs. 4, 5) morphological features of the observed specimens corresponds to $P$. novenarius, such as the number of antennal segments, and antennal armature in females (8s, 12s, 6s, 5s, 2s + ae, 2s, 2s + ae, $7 \mathrm{~s}+\mathrm{ae})$, and males (8s + ae, 4s, 2s, 2s + ae, 2s, 2s, 2s, 2s, 2s + ae, 2s, 2s, 2s, 6s, 3s + ae, 11s + ae). All these features were stable in all the observed specimens of all collections.

Ornamentation of buccal and thoracic appendages corresponds to the mentioned species, including the presence of large setules on coxal, distal margin of P1-P3, and the absence of ornamentation in this distal margin on P4 (at least not identifiable with light microscopy). Furthermore, features related to sexual dimorphisms, such as the ornamentation of antennal basis, Enp3P1, and Enp3P3, also corresponds with P. novenarius.

Abundances of $P$. novenarius (including adult males, females and different instars) and arsenic concentrations are shown in Fig. 6 . Abundances for copepodites (I-V) were slightly higher in dry $\left(1.50 \mathrm{ind} / \mathrm{L}^{-1}\right)$ than rainy $\left(1.02 \mathrm{ind} / \mathrm{L}^{-1}\right)$, whereas nauplii varied from 0.3 (rainy) to $1.51 \mathrm{ind} / \mathrm{L}^{-1}$ (dry). Abundances for adult females varied from 1.03 (rainy) to $4.46 \mathrm{ind} / \mathrm{L}^{-1}$ (dry), which were superior to adult males with 0.07 and 0.21 ind/ $\mathrm{L}^{-1}$ for rainy and dry, respectively. Although the abundances were similar in both seasons, the dry season showed the highest abundances for nauplii, copepodites (IIV) and adults female and male, which corresponds to the highest arsenic concentration $\left(58 \mathrm{mg} / \mathrm{L}^{-1}\right)$. On the other hand, the lowest abundances correspond to the lowest arsenic concentration (54.5 mg/L $\mathrm{L}^{-1}$ ) (Fig. 6).

Body size was large in rainy with $637.19 \pm 42 \mu \mathrm{m}$ for females and $650 \pm 37 \mu \mathrm{m}$ for males. In dry it was $607.3 \pm 28 \mu \mathrm{m}$ and $616.5 \pm 40 \mu \mathrm{m}$, for females and males respectively (Fig. 7). The Mann-Whitney $U$ test demonstrated a significant difference in body size by season $(U=1284.5, p<0.05, n=87)$ as well as by arsenic concentration $(U=1284.5, p<0.05, n=87)$. Adult sex ratios were skewed towards the dominance of females in both seasons $($ rainy $=15: 1$, dry $=21: 1)$ (Table 1).

Table 1

Seasonal sex ratios of Paracyclops novenarius in the study area

\begin{tabular}{|llll|}
\hline \multirow{2}{*}{ Season } & \multicolumn{2}{l}{ Number of individuals sexed } & Sex ratio F:M \\
\cline { 2 - 3 } & Females & Males & \\
\hline Rainy & 103 & 7 & $15: 1$ \\
\hline Dry & 446 & 21 & $21: 1$ \\
\hline
\end{tabular}

The values obtained for the physical and chemical variables and arsenic concentrations are presented in Table 2 . The maximum value of dissolved oxygen was found in rainy $\left(4.0 \mathrm{mg} / \mathrm{L}^{-1}\right)$, whereas the lowest value was found in dry $\left(1.6 \mathrm{mg} / \mathrm{L}^{-1}\right)$. The maximum temperature was found in rainy $\left(22.8^{\circ} \mathrm{C}\right)$, and the minimum in dry $\left(20.0^{\circ} \mathrm{C}\right)$. The lowest value for electric conductivity was in dry $\left(3247 \mu \mathrm{S} / \mathrm{cm}^{3}\right)$, whereas the maximum was in rainy $\left(3407 \mu \mathrm{S} / \mathrm{cm}^{3}\right)$. The $\mathrm{pH}$ values were similar with 6.9 in rainy and 7.0 in dry. Salinity values ranged from 1.8 to $1.7 \mathrm{PSU}$. Arsenic concentration was $54.5 \mathrm{mg} / \mathrm{L}^{-1}$ in rainy and increased to $58 \mathrm{mg} / \mathrm{L}^{-1}$ in dry.

Table 2

Physical and chemical variables and arsenic concentration for each season

\begin{tabular}{|lllllll|}
\hline Season & $\mathrm{DO}\left(\mathrm{mg} / \mathrm{L}^{-1}\right)$ & $\mathrm{T}\left({ }^{\circ} \mathrm{C}\right)$ & $\mathrm{EC}\left(\mu \mathrm{S} / \mathrm{cm}^{3}\right)$ & $\mathrm{pH}$ & Salinity (PSU) & Arsenic $\left(\mathrm{mg} / \mathrm{L}^{-1}\right)$ \\
\hline Rainy & 4.0 & 22.8 & 3407 & 6.9 & 1.8 & 54.5 \\
\hline Dry & 1.6 & 20.0 & 3247 & 7.0 & 1.7 & 58 \\
\hline
\end{tabular}

\section{Discussion}


In the world, around 30 species and subspecies of the genus Paracyclops Claus 1893 have been recorded in different types of freshwater habitats, distributed in temperate-cold latitudes and in tropical areas in which the genus tends to present more species (Karaytug and Boxshall 1998a, b; Karaytug et al. 1998; Mercado-Salas and Suárez-Morales 2009). In Mexico, four species of Paracyclops have been inventoried (Suárez-Morales et al. 2020). At the study site, previous work reported the presence of the species P. chiltoni (Mendoza-Chávez et al. 2021); however, in this work, the detailed morphological analysis by scanning and light microscopy confirmed that it is $P$. novenarius.

This species was reported for the first time in Colombia by Reid (1987), later by Gaviria (1994), and Gaviria and Aranguren (2007), inhabiting artificial asbestos containers, and it is well known that this material is carcinogenic (Barrera et al. 2010). Asbestos is composed of silicate fibers; the mineral is obtained in open quarries or shallow mines (Castellano-Alvarado et al. 1960), and according to its physical characteristics, it can be composed of $\mathrm{SiO}_{4}{ }^{-}$. In addition, in the region where $P$. novenarius was reported, the presence of heavy metals such as $\mathrm{Cu}, \mathrm{Cr}$, $\mathrm{Ni}$, and $\mathrm{Zn}$, have been reported, which exceed the contamination limits established by the EPA (Collazos-Santos, 2014). Probably, there is a relationship between the habitat of $P$. novenarius, living in environments with some pollutants, but further analysis is required to understand this.

In Mexico, it has not been reported in previous works (Mercado-Salas and Suárez-Morales 2009, 2012; Suárez-Morales 2020); thus, this is the first record of this species in Mexico. Additionally, P. novenarius is living in this site that significantly exceeds the concentration of arsenic considered lethal for zooplankton (3 mg/ $\left.\mathrm{L}^{-1}\right)$ (Chen et al. 1999), and could be recognized as an extremophile organism due to the ability to thrive in this habitat which for other organisms might be intolerably hostile or even lethal (Rampelotto 2013; Mendoza-Chávez et al. 2021).

The anamorphic development of $P$. novenarius during its naupliar, copepodid and adult instars observed in the freshwater analyzed system was typical of the cyclopoids, even with the extremely high and seasonally variable arsenic concentration in the analyzed population. Some differences were found in comparison with additional freshwater Cyclopidae species whose development is known (Dahms and Fernando 1992; Ferrari 2000); for instance, the number of added segments on each appendage or the number of setulae on each appendage segment, but this appears to be more related to the recognizable morphological differences between species, even at the earliest developmental stages (Suárez-Morales et al. 2007), than the effect of the contaminant (arsenic) on the P. novenarius morphology.

Morphological differences in other zooplankton groups (Cladocera and Rotifera) have been recorded because of metals such as $\mathrm{Cd}$, Cu, or Pb (Gama-Flores et al. 2007; Pérez and Hoang 2017; Xue et al. 2017; Araujo et al. 2019; Pérez-Yañez et al. 2019). But to our knowledge, no morphological effect during the development of copepods has been recorded in the presence of metals or metalloids: the analyzed population appears not to be the exception.

Laboratory studies have shown that metals and metalloids affect copepods in a minor way in comparison with cladocerans and rotifers because these are relatively more tolerant to toxic action; this could be explained due to their ability to accumulation of heavy metals in the body (Gagneten and Paggi 2009; Caumette et al. 2011; Mendoza-Chávez et al. 2021).

On average, the abundances of adults were similar to the values reported by Gagneten and Paggi (2009) for the order Cyclopoida inhabiting water polluted by heavy metals $\left(0.033-1.844 \mathrm{ind} / \mathrm{L}^{-1}\right)$. However, these values are low in comparison with other copepods inhabiting other aquatic systems without pollutant agents (up to 1,182 ind/L-1) (Gerten and Adrian 2002; Mitsuka and Henry 2002; Cervantes-Martínez et al. 2005; Sarma et al. 2011; Gómez-Márquez et al. 2013; Cervantes-Martínez and Gutiérrez-Aguirre 2015), this suggests that arsenic concentration could play a key role in the abundances of $P$. novenarius; nevertheless, further studies are necessary to confirm this. On the other hand, individuals with egg sacs were observed along the two seasons studied, reflecting a constant development of all stages. Thus, even in these high concentrations of arsenic, $P$. novenarius reproduces; this could explain the presence of copepodites and nauplii in the periods surveyed.

Adult female and male lengths were within the ranges (570-880 $\mu \mathrm{m}$ for females and 540-640 $\mu \mathrm{m}$ for males) reported by Reid (1987) for this species. On average, males were larger than females, which differs from the sexual dimorphism typically found in Copepoda, where males are smaller than females (Hirst and Kiørboe 2014). Statistical results showed a significant difference in body size by season and these variations could be related to factors such as temperature and food availability (Plath and Boersma 2001; Lin et al. 2013).

A significant difference in body size by arsenic concentration was found. This differs from other zooplanktonic groups such as cladocerans, where body growth was not significantly altered by arsenic (Hoang et al. 2007). However, differences in mean length between individuals by season are minimal, compared with other studies where copepods showed a more significant difference in body size but without any pollutant agent (Cervantes-Martínez et al. 2005; Belmonte et al. 2006; Cervantes-Martínez 2021).

According to Fisher's principle, sex ratio (F:M) is expected to be 1:1 in a natural environment or skewed to the sex in which the female invested least in the embryo phase (Hirst et al. 2010). In this study sex ratio was skewed to females in both rainy and dry season with 15:1 and 21:1, respectively, which agreed with adult females outnumbering males in copepods populations (Hirst and Kiørboe 2002; Kiørboe 2006).

Water temperature and dissolved oxygen are variables inversely related (Lewis 1987; Khani and Rajaee 2017; Koralay et al. 2018); nevertheless, in this study, a direct relationship was observed, these variations might be explained more by biological effects (photosynthesis-respiration) than by physical aspects (Cervantes-Martínez and Gutiérrez-Aguirre 2015). pH values were closer to the neutrality, probably due to the limestone buffer, according to Razo et al. (2004) and Grochowska (2020). The electrical conductivity recorded in this work $\left(3247-3407 \mu \mathrm{S} / \mathrm{cm}^{3}\right)$ is characteristic of freshwater systems in central-north Mexico due to the dominant processes of evaporation and salt precipitation (Alcocer and Escobar 1996). According to salinity, this system is classified as oligohaline (Strydom et al. 2002). In general, values of physical and chemical variables were lower than the reported in other studies (Copaja et al. 2016; Ali et al. 2016) in water bodies polluted by metals and metalloids. 
Finally, arsenic concentrations were within the values $\left(35-155 \mathrm{mg} / \mathrm{L}^{-1}\right.$ ) reported by Martínez-Villegas et al. (2013) and Mendoza-Chávez et al. (2021) at this site. These values exceeded the Mexican guidelines for the conservation of aquatic life $\left(02 . \mathrm{mg} / \mathrm{L}^{-1}\right)$ and for water quality $\left(0.05 \mathrm{mg} / \mathrm{L}^{-1}\right)$ as well as international guidelines (EPA 1994; DOF 1994, 1998).

\section{Conclusions}

In this study, we reported for the first time in central-north Mexico the neotropical copepod $P$. novenarius. Additionally, this species was found inhabiting high arsenic concentrations. The morphological analysis allows us to conclude that arsenic does not affect the morphology in all development stages, and apparently, it affects some ecological aspects (body size, abundance, sex ratio). Further studies are required to know in detail more specific effects and mechanisms of action of arsenic on the life cycle of $P$. novenarius. Finally, knowing the probable impact of this metalloid on ecological characteristics such as abundance, sizes, distribution, and detailed morphology of plankton in a region recognized for high arsenic concentration in its aquifers, could lay the basis for using regional fauna for health analysis of continental aquatic systems in the region.

\section{Declarations}

Ethics approval and consent to participate. We collected from several freshwater ecosystems in Mexico. However, Mexican laws do not protect Zooplankton, thus, no specific permits for this type of field study are needed.

Consent for publication. Not applicable.

Availability of data and materials. The authors declare that the data supporting the findings of this study are available within the article.

Competing interests. The authors declare that they have no competing interests.

Funding. Scholarship granted for unique support ( $\mathrm{CH}-22478$ Scholarships Unique Support) from the Potosino Institute of Scientific and Technological Research A.C. (IPICYT). University of Quintana Roo, Cozumel.

Authors' contribution. All authors contributed to the study conception and design. Material preparation, data collection and analysis were performed by JLUC, ACM and MAGA. The first draft of the manuscript was written by JLUC and all authors commented on previous versions of the manuscript. All authors read and approved the final manuscript.

Acknowledgements. The authors thank Laboratory of Limnology and Tropical Ecology of University of Quintana Roo, Cozumel. Nadia Valentina MartínezVillegas and Yadira Jazmín Mendoza-Chávez for the facilities and support in field work. National Laboratory of Agricultural, Medical and Environmental Biotechnology (LANBAMA-IPICYT) for the determination of arsenic in water samples. Facilities to use the Scanning Microscopy JEOL SM-6010 were provided by El Colegio de la Frontera Sur (ECOSUR, Chetumal). José Ángel Cohuó Colli kindly allowed us to review ECOCH-Z specimens. Sarahi Jaime helped us in the elaboration of some figures presented in this work.

\section{References}

1. Alcocer A, Escobar E (1996) Limnological regionalization of Mexico. Lakes and Reservoirs: Research and Management 2:55-69. https://doi.org/10.1111/j.1440-1770.1996.tb00048.x

2. Ali MM, Ali ML, Islam MS, Rahman MZ (2016) Preliminary assessment of heavy metals in water and sediment of Karnaphuli River, Bangladesh. Environmental Nanotechnology, Monitoring \& Management 5:27-35 https://doi.org/10.1016/j.enmm.2016.01.002

3. Araujo GS, Pavlaki MD, Soares AMVM, Abessa DMS, Loureiro S (2019) Bioaccumulation and morphological traits in a multi-generation test with two Daphnia species exposed to lead. Chemosphere 219:636-644. https://doi.org/10.1016/j.chemosphere.2018.12.049

4. Barrera RR, Chavarría GJ, Morales FJ (2010). Malignant mesothelioma: Clinical and pathological features from 247 cases. Rev Chil Enf Respir 26:134-140 http://dx.doi.org/10.4067/S0717-73482010000300003

5. Belmonte G, Alfonso G, Moscatello S (2006) Copepod fauna (Calanoida and cyclopoida) in small ponds of the Pollino National Park (South Italy), with notes on seasonality and biometry of species. J Limnol 65:107-113. https://doi.org/10.4081/jlimnol.2006.107

6. Castellano-Alvarado L, Enriquez JL, Barron D (1960). Asbestosis. Journal of Public Health of Mexico 2:557-566. (In Spanish)

7. Caumette G, Koch I, Estrada E, Reimer KJ (2011) Arsenic speciation in plankton organisms from contaminated lakes: transformations at the base of the freshwater food chain. Environ Sci Technol 45:9917-9923. https://doi.org/10.1021/es2025092

8. CEFIM (2016) Monographs of the Municipalities of Mexico: Matehuala, San Luis Potosi. http://cefimslp.gob.mx/monografias_municipales/2012/venado/files/venado.12.pdf. Accessed 26 May 2021 (in Spanish)

9. Cervantes-Martínez A, Gutiérrez-Aguirre MA (2015) Physicochemistry and zooplankton of two karstic sinkholes in the Yucatan Peninsula, Mexico. J Limnol 74:382-393 https://doi.org/10.4081/jlimnol.2014.976

10. Cervantes-Martínez A, Gutiérrez-Aguirre MA, Suárez-Morales E, Jaime S (2021) Phenetic and Genetic Variability of Continental and Island Populations of the Freshwater Copepod Mastigodiaptomus ha Cervantes, 2020 (Copepoda): A Case of Dispersal? Diversity 2021,13:279. https://doi.org/10.3390/d13060279

11. Cervantes-Martínez A, Elías-Gutiérrez ME, Gutiérrez-Aguirre MA, Kotov AA (2005) Ecological remarks on Mastigodiaptomus nesus Bowman, 1986 (Copepoda: Calanoida) in a Mexican karstic sinkhole. Hydrobiologia 542:95-102. https://doi.org/10.1007/s10750-004-2488-4

Page 5/14 
12. Chen CY, Sillett KB, Folt CL, Whittemore SL, Barchowsky A (1999) Molecular and demographic measures of arsenic stress in Daphnia pulex. Hydrobiologia 401:229-238. https://doi.org/10.1023/A:1003738427354

13. Collazos-Santos MF (2014). Definition of discharge objectives in Buenaventura Bay development phase I. Master's theses. Autonomous University of Occident, Cali, Colombia.https://red.uao.edu.co/bitstream/handle/10614/5885/T03915.pdf?sequence=1\&isAllowed=y. Accessed 15 June 2021 (In Spanish)

14. Copaja SV, Nuñez VR, Gigliola SM, González GL, Vila I, Véliz D (2016) Heavy metal concentrations in water and sediments from affluents and effluents of Mediterranean chilean reservoirs. J Chil Chem Soc 61:2797-2804. https://dx.doi.org/10.4067/S0717-97072016000100011

15. Dahms HU, Fernando CH (1992) Naupliar development of Mesocyclops aequatorialis similis and Thermocyclops consimilis (Copepoda: Cyclopoida) from Lake Awasa, a tropical rift valley lake in Ethiopia. Can J Zool 70:2283-2297. https://doi.org/10.1139/z92-306

16. DOF (1994) NOM-117-SSA1-1994 (Mexican Official Norm). Secretariat of Health, Mexico. http://www.ordenjuridico.gob.mx/Documentos/Federal/wo69541.pdf. Accessed 2 June 2021 (In Spanish)

17. DOF (1998) NOM-001-SEMARNAT- 1996 (Mexican Official Norm). Secretariat of Health, Mexico. https://www.profepa.gob.mx/innovaportal/file/3290/1/nom-001-semarnat-1996.pdf. Accessed 2 June 2021 (In Spanish)

18. Dur, G., Souissi, S., Schmitt, F.G., Cheng, S., Hwang, J.S., 2012. Sex ratio and mating behavior in the calanoid copepod Pseudodiaptomus annandalei. Zool Stud 51:589-597.

19. EPA (1994) Method 200.7: Determination of metals and trace elements in water and wastes by inductively coupled plasma-atomic emission spectrometry, Revision 4.4. Cincinnati, Ohio. https://www.epa.gov/sites/production/files/2015-06/documents/epa-200.7.pdf. Accessed 2 June 2021

20. Ferrari FD (2000) Patterns of setal numbers conserved during early development of swimming legs of Copepoda (Crustacea). Hydrobiologia 417:81-90. https://doi.org/10.1023/A:1003895004611

21. Gagneten AM, Paggi JC (2009) Effects of Heavy Metal Contamination ( $\mathrm{Cr}, \mathrm{Cu}, \mathrm{Pb}, \mathrm{Cd})$ and Eutrophication on Zooplankton in the Lower Basin of the Salado River (Argentina). Water Air Soil Pollut 198:317-334. https://doi.org/10.1007/s11270-008-9848-z

22. Gama-Flores JL, Castellanos-Paez ME, Sarma SS, Nandini S (2007) Effect of pulsed exposure to heavy metals (copper and cadmium) on some population variables of Brachionus calyciflorus Pallas (Rotifera: Brachionidae: Monogononta). Hydrobiologia 593:201-208. https://doi.org/10.1007/s10750-007-9042-0

23. Gaviria S (1994) The free-living copepods (Arthropoda, Crustacea) of the continental waters of Colombia. Rev Acad Colomb Cienc 19: $361-385$ (In Spanish)

24. Gaviria S, Aranguren N (2007) Free-living species of the Copepoda (Arthropoda, Crustacea) subclass of the Colombian continental waters. Biota Colombiana, 8:53-68. (In Spanish)

25. Gerten D, Adrian R (2002) Species-specific changes in the phenology and peak abundance of freshwater copepods in response to warm summers. Freshwater Biology 47:2163-2173. https://doi.org/10.1046/j.1365-2427.2002.00970.x

26. Gómez-Márquez JL, Peña-Mendoza B, Guzmán-Santiago JL, Gallardo-Pineda V (2013) Zooplankton composition, abundance and water quality in a microreservoir at Morelos State. Hidrobiológica 23:227-240. (In Spanish)

27. Grochowska J (2020) Assessment of Water Buffer Capacity of Two Morphometrically Different, Degraded, Urban Lakes. Water $2020,12,1512$. https://doi.org/10.3390/w12051512

28. Gutiérrez MF, Gagneten AM (2011) Effects of metals on freshwater microcrustaceans. Methodological advances and potentiality of cladocerans and copepods as test organisms. Revista Peruana de Biología 18:389-396. https://doi.org/10.15381/rpb.v18i3.460 (In Spanish)

29. Gutiérrez MF, Gagneten AM, Paggi JC (2010) Copper and Chromium Alter Life Cycle Variables and the Equiproportional Development of the Freshwater Copepod Notodiaptomus conifer (SARS). Water Air Soil Pollut 213:275-286. https://doi.org/10.1007/s11270-010-0383-3

30. Gutierrez MF, Paggi JC, Gagneten AM (2012) Microcrustaceans escape behavior as an early bioindicator of copper, chromium and endosulfan toxicity. Ecotoxicology 21:428-438. https://doi.org/10.1007/s10646-011-0803-1

31. Hirst AG, Bonnet D, Conway DVP, Kiørboe T (2010) Does predation controls adult sex ratios and longevities in marine pelagic copepods?. Limnol Oceanogr 55:2193-2206. https://doi.org/10.4319/lo.2010.55.5.2193

32. Hirst AG, Kiørboe T (2002) Mortality of marine planktonic copepods: global rates and patterns. Mar Ecol Prog Ser 230:195-209. https://doi.org/10.3354/meps230195

33. Hirst AG, Kiørboe T (2014) Macroevolutionary patterns of sexual size dimorphism in copepods. Proc R Soc B 28:20140739. http://dx.doi.org/10.1098/rspb.2014.0739

34. Hoang TC, Gallagher JS, Klaine SJ (2007) Responses of Daphnia magna to pulsed exposures of arsenic. Environ Toxicol 22:308-317. https://doi.org/10.1002/tox.20242

35. Huys R, Boxshall GA (1991) Copepod Evolution. The Ray Society, London.

36. INEGI (2002) Synthesis of Geographic Information of San Luis Potosí. Institute of Statistics, Geography and informatics of Mexico. https://www.inegi.org.mx/contenidos/productos/prod_serv/contenidos/espanol/bvinegi/productos/historicos/2104/702825224240/702825224240_2.pc Accessed 16 May 2021

37. Karaytug S, Boxshall GA (1998a). Partial revision of Paracyclops Claus, 1893 (Copepoda, Cyclopoida, Cyclopidae) with descriptions of four new species. Bull Nat Hist Mus Lond (Zool) 64:111-205

38. Karaytug S, Boxshall GA (1998b). The Paracyclops fimbriatus-complex (Copepoda, Cyclopoida): a revision. Zoosystema 20:563-602. 
39. Karaytug S, Boxshall GA (1999) Antennules of the male of Paracyclops (Copepoda): functional significance and their importance in systematics. Journal of Crustacean Biology 19:371-379. https://doi.org/10.1163/193724099X00187

40. Karaytug S, Defaye D, Boxshall GA (1998) Two new species of Paracyclops (Copepoda: Cyclopoida, Cyclopidae) from Africa. Hydrobiologia 382:119-136. https://doi.org/10.1023/A:1003473215548

41. Khani S, Rajaee T (2017) Modeling of Dissolved Oxygen Concentration and Its Hysteresis Behavior in Rivers Using Wavelet Transform-Based Hybrid Models. CLEAN Soil Air Water 45. https://doi.org/10.1002/clen.201500395

42. Kiørboe T (1998) Population regulation and role of mesozooplankton in shaping marine pelagic food webs. Hydrobiologia 363:13-27. https://doi.org/10.1023/A:1003173721751

43. Kiørboe T (2006) Sex, sex-ratios, and the dynamics of pelagic copepod populations. Oecologia 148:40-50. https://doi.org/10.1007/s00442-005-0346-3

44. Koralay N, Kara O, Kezik U (2018) Effects of run-of-the-river hydropower plants on the surface water quality in the Solakli stream watershed, Northeastern Turkey. Water and Environment Journal 32:412-421. https://doi.org/10.1111/wej.12338

45. Lewis Jr WM (1987) Tropical limnology. Annual Review of Ecology and Systematics 18:159-184. https://doi.org/10.1146/annurev.es.18.110187.001111

46. Lin KY, Sastri AR, Gong GC, Hsieh CH (2013) Copepod community growth rates in relation to body size, temperature, and food availability in the East China Sea: A test of metabolic theory of ecology. Biogeosciences 10:1877-1892. https://doi.org/10.5194/bg-10-1877-2013

47. Martínez-Villegas N, Briones-Gallardo R, Ramos-Leal JA, Avalos-Borja M, Castañon-Sandoval AD, Razo-Flores E, Villalobos M (2013) Arsenic mobility controlled by solid calcium arsenates: a case study in Mexico showcasing a potentially widespread environmental problem. Environ Pollut 176:114-122 https://doi.org/10.1016/j.envpol.2012.12.025

48. Mendoza-Chávez YJ, Uc-Castillo JL, Cervantes-Martínez A, Gutiérrez-Aguirre MA, Castillo-Michel H, Loredo-Portales R, SenGupta B, Martínez-Villegas, N (2021) Paracyclops chiltoni inhabiting water highly contaminated with arsenic: Water chemistry, population structure, and arsenic distribution within the organism. Environ Pollut 284:117155. https://doi.org/10.1016/j.envpol.2021.117155

49. Mercado-Salas N, Suárez-Morales E (2009) A new species and illustrated records of Paracyclops claus, 1893 (copepoda: Cyclopoida: cyclopinae) from Mexico. J Nat Hist 43:2789-2808. https://doi.org/10.1080/00222930903108462.

50. Mercado-Salas NF, Suárez-Morales E (2012) Morphology, diversity, and distribution of the Cyclopoida (Copepoda) from arid areas of central-north. Mexico. II. Eucyclopinae and biogeographic analysis. Hidrobiológica 22:99-124. (In Spanish)

51. Mitsuka PM, Henry R (2002) The fate of copepod populations in the Paranapanema River (São Paulo, Brazil), downstream from the Jurumirim dam. Braz arch biol technol 45:479-490. https://doi.org/10.1590/S1516-89132002000600012

52. Ordóñez-López U, Ornelas-Roa M (2003) Variations of the planktonic copepod community in the estuarine-coastal gradient of Celestun, Yucatan, Mexico. Hidrobiológica 13:231-238. (In Spanish)

53. Pérez E, Hoang TC (2017) Chronic Toxicity of Binary-Metal Mixtures of Cadmium and Zinc to Daphnia magna. Environmental Toxicology and Chemistry 36:2739-2749. http://dx.doi.org/10.1002/etc.3830

54. Pérez-Yañez D, Soriano-Martínez DR, Damian-Ku ME, Cejudo-Espinosa E, Alvarado-Flores J (2019) Cadmium and morphological alterations in the rotifer Philodina cf. roseola (Bdelloidea: Philodinidae) and the worm Aeolosoma hemprichi (Annelida: Aeolosomatidae). Revista de Biología Tropical 67:14061417

55. Plath K, Boersma M (2001) Mineral limitation of zooplankton: Stoichiometric constraints and optimal foraging. Ecology 82:1260-1269. https://doi.org/10.1890/0012-9658(2001)082[1260:MLOZSC]2.0.CO,2

56. Rampelotto PH (2013) Extremophiles and Extreme Environments. Life 3:482-485. https://doi.org/10.3390/life3030482

57. Ravenscroft P, Brammer H, Richards K (2009) Arsenic Pollution: A Global Synthesis. Singapore.

58. Razo I, Carrizales L, Castro J, Díaz-Barriga F, Monroy M (2004) Arsenic and heavy metal pollution of soil, water and sediments in a semi-arid climate mining area in Mexico. Water Air Soil Pollut 152:129-152. https://doi.org/10.1023/B:WATE.0000015350.14520.c1

59. Reid JW (1987) Some cyclopoid and harpacticoid copepods from Colombia, including descriptions of three new species. PROC BIOL SOC WASH 100:262271.

60. Ruíz-Huerta EA, de la Garza Varela A, Gómez-Bernal JM, Castillo F, Avalos-Borja M, SenGupta B, Martínez-Villegas N (2017) Arsenic contamination in irrigation water, agricultural soil and maize crop from an abandoned smelter site in Matehuala, Mexico. J Hazard Mater 339:330-339. https://doi.org/10.1016/j.jhazmat.2017.06.041

61. Sarma SSS, Osnaya-Espinosa LR, Aguilar-Acosta CR, Nandini S (2011) Seasonal variations in zooplankton abundances in the Iturbide reservoir (Isidro Fabela, State of Mexico, Mexico). Journal of Environmental Biology 32:473.

62. Strydom NA, Whitfield AK, Wooldridge TH (2003) The role of estuarine type in characterizing early stage fish assemblages in warm temper-ate estuaries, South Africa. Afric Zool 38:29-43. https://doi.org/10.1080/15627020.2003.11657192

63. Suárez-Morales E (2020) Diversity and distribution of the copepods (Cyclopoida) of the arid zones of North-Central Mexico. National Commission for the Knowledge and Use of Biodiversity. https://doi.org/10.15468/vbhfeb. Accessed 23 May 2021 (In Spanish)

64. Suárez-Morales E, Gutiérrez-Aguirre MA, Gómez S, Perbiche-Neves G, Previatelli D, dos Santos-Silva EN, da Rocha CEF, Mercado-Salas NF, Marques TM, Cruz Quintana Y, Santana Piñeros AM (2020). Class Copepoda. In: Damborenea C, Damborenea DC, Rogers, Thorp JH (eds.) Keys to Neotropical and Antarctic Fauna, Thorp and Covich's Freshwater, Invertebrates. Volume V. Fourth Edition. ISBN: 978-0-12-804225-0

65. Suárez-Morales E, Wyngaard G, Gutiérrez-Aguirre MA, Constanzo J (2007) Life history traits of Mesocyclops thermocyclopoides Harada, 1931 (Copepoda, Cyclopoida) with observations on naupliar morphology. Crustaceana 80:1205-1222. https://doi.org/10.1163/156854007782321146 
66. Villagran DM, Fernández-Severini MD, Biancalana F, Spetter CV, Fernández EM, Marcovecchio JE (2019) Bioaccumulation of heavy metals in mesozooplankton from a human-impacted south western Atlantic estuary (Argentina). J Mar Res 77:217-241.

https://doi.org/10.1357/002224019826887362

67. Xue YH, Yang XX, Zhang G., Xi YL (2017) Morphological differentiation of Brachionus calyciflorus caused by predation and coal ash pollution. Sci Rep 7:15779. https://doi.org/10.1038/s41598-017-16192-w

\section{Figures}
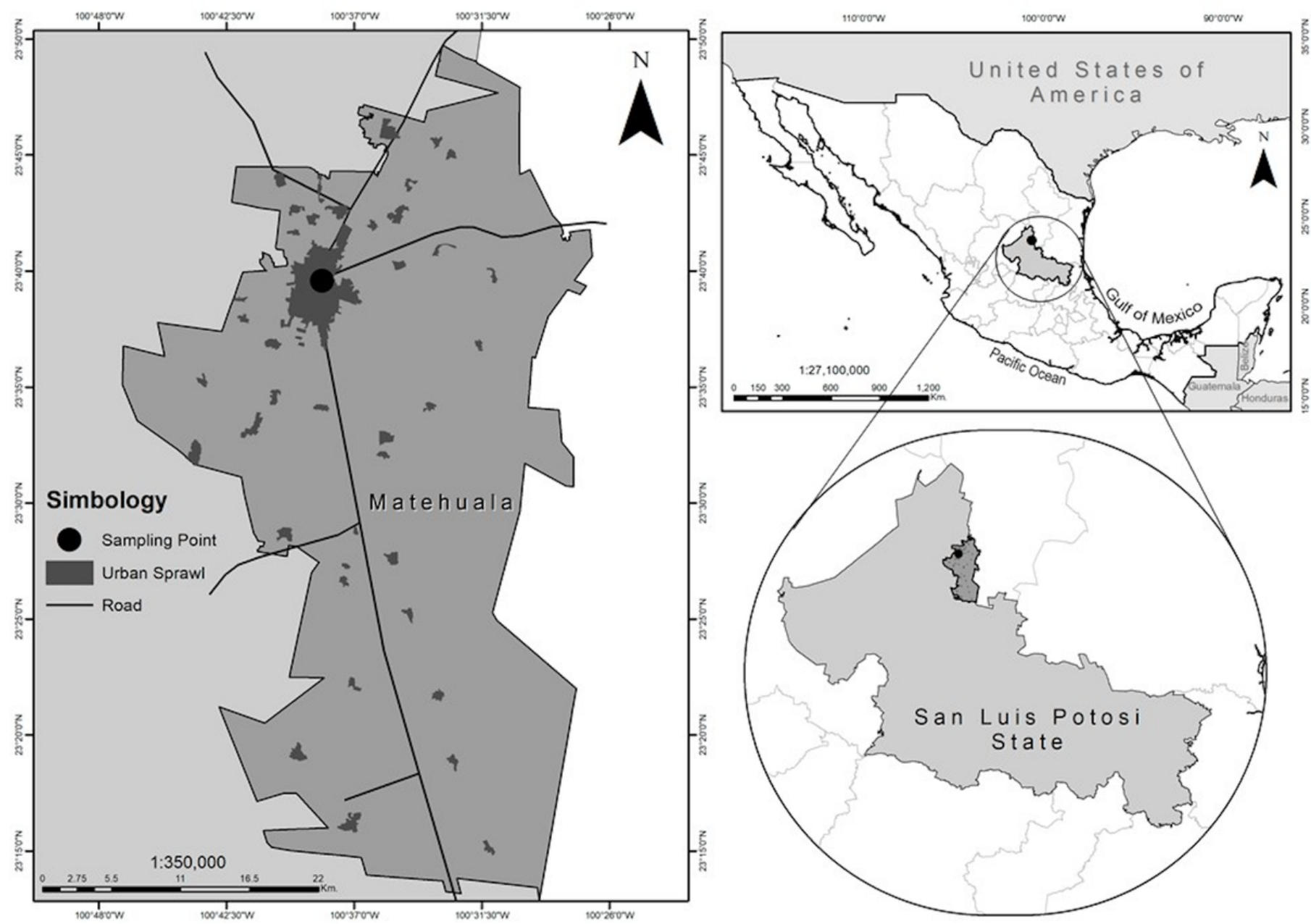

\section{Figure 1}

Location of the study area in Matehuala, San Luis Potosi 


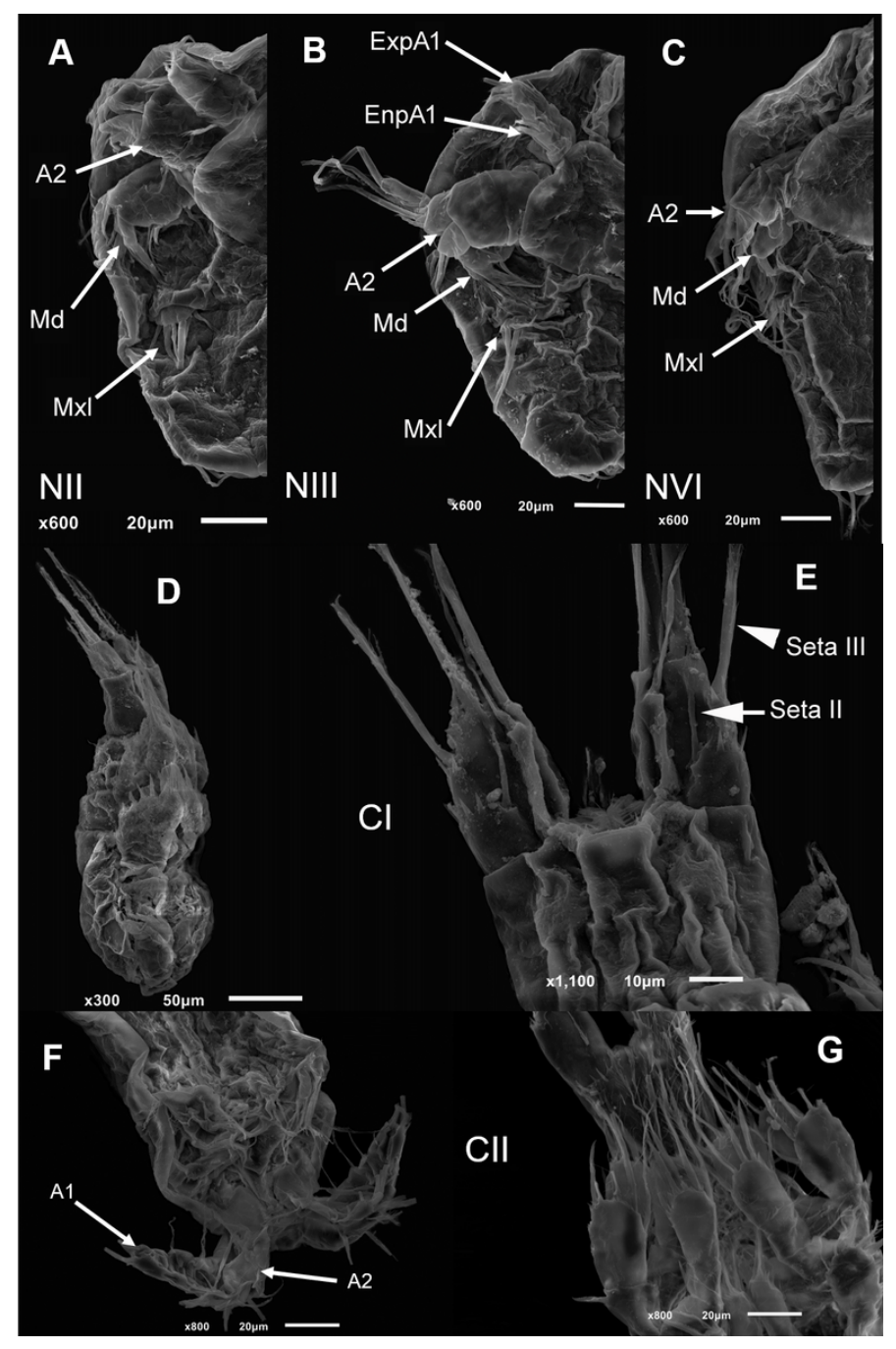

\section{Figure 2}

Paracyclops novenarius, immature stages (collection 2017). a-c) Nauplii II-VI, d) Copepodite Cl, lateral e) Cl, anal somite and caudal rami, ventral f) Copepodite Cll, prosome ventral g) Cll, prosome and urosome, ventral 


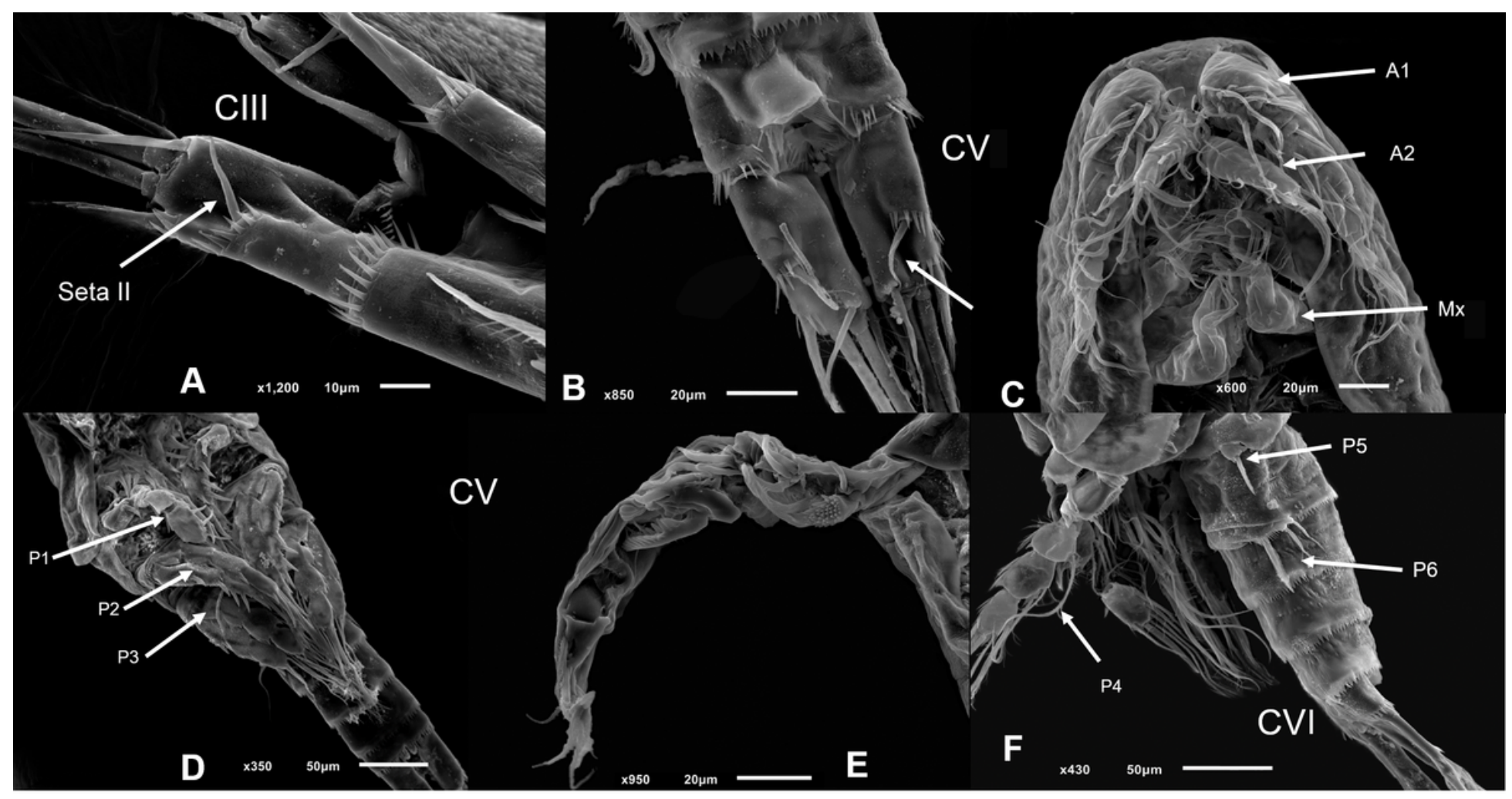

Figure 3

Paracyclops novenarius, immature stages (collection 2017). A) Copepodite III, caudal rami, B) Copepodite V, anal somite and caudal rami, C) Copepodite V, prosome, ventral, D) Copepodite V, P1-P3, E) Copepodite V, A1, F) Copepodite VI, lateral 


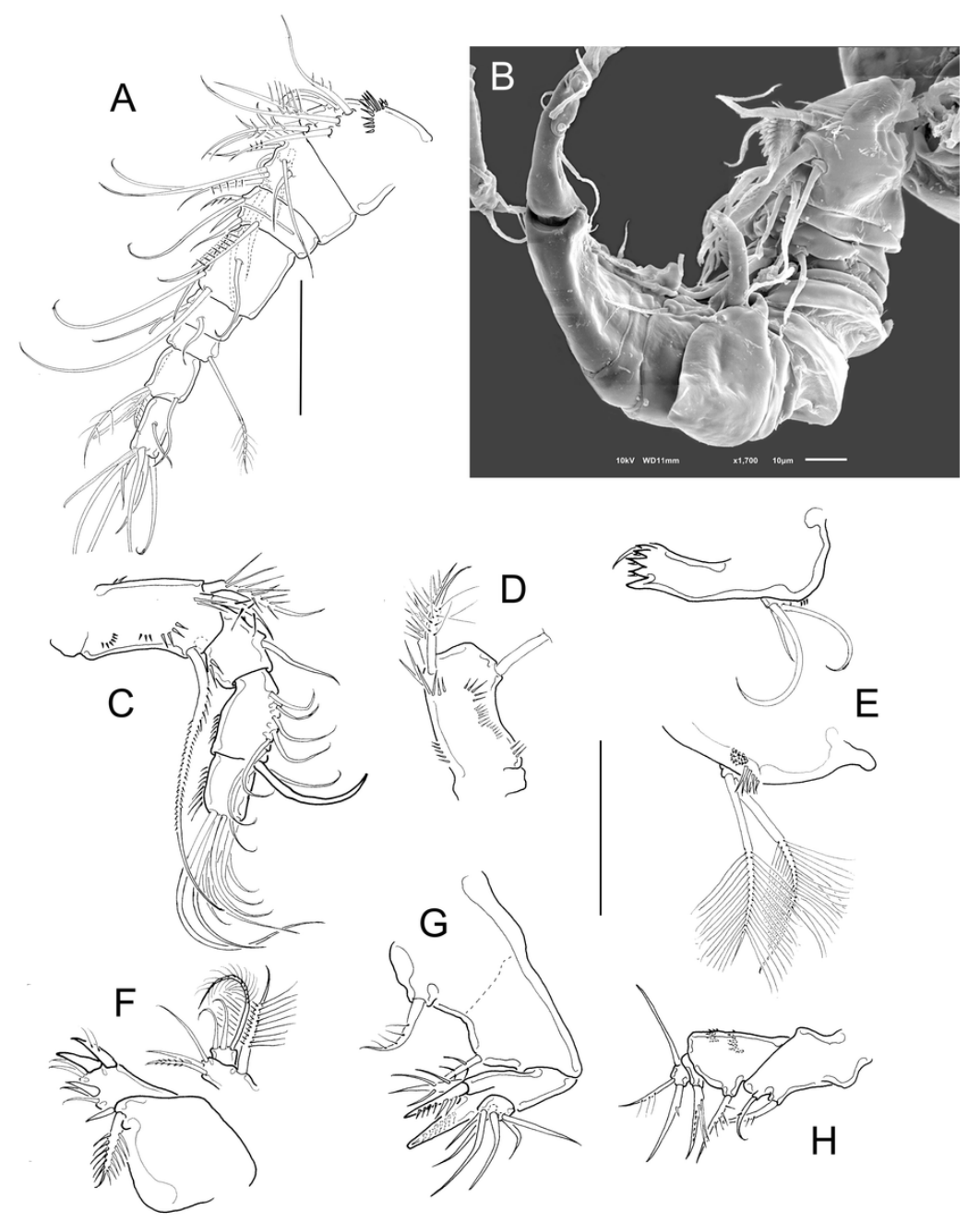

\section{Figure 4}

Paracyclops novenarius, adult A) Antennule, female, B) Antennule, male, C) Antenna, female, D) Antenna, basis, male, E) Mandible, posterior, anterior view separated, F) Maxillule, G) Maxilla, H) Maxilliped 


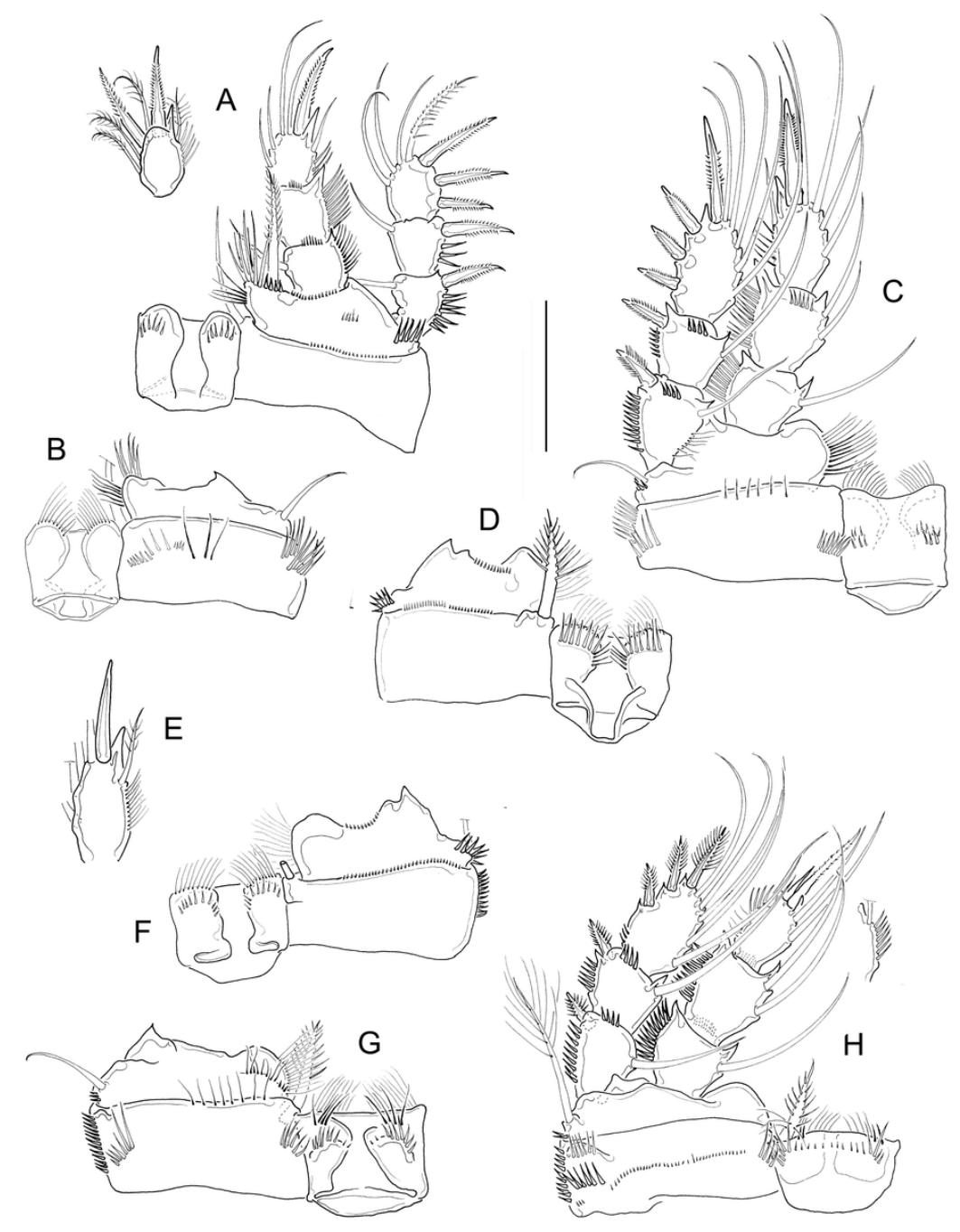

Figure 5

Paracyclops novenarius, adult A) First leg, frontal, female, Enp3P1 separated, male, B) First leg, caudal, C) Second leg, caudal, D) second leg, frontal, E) Enp3P3, male: F) Third leg, frontal, G) Third leg, caudal, H) Fourth leg, caudal 


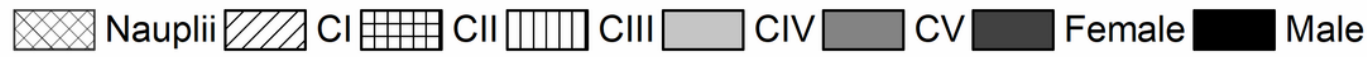 \\ - As concentration}

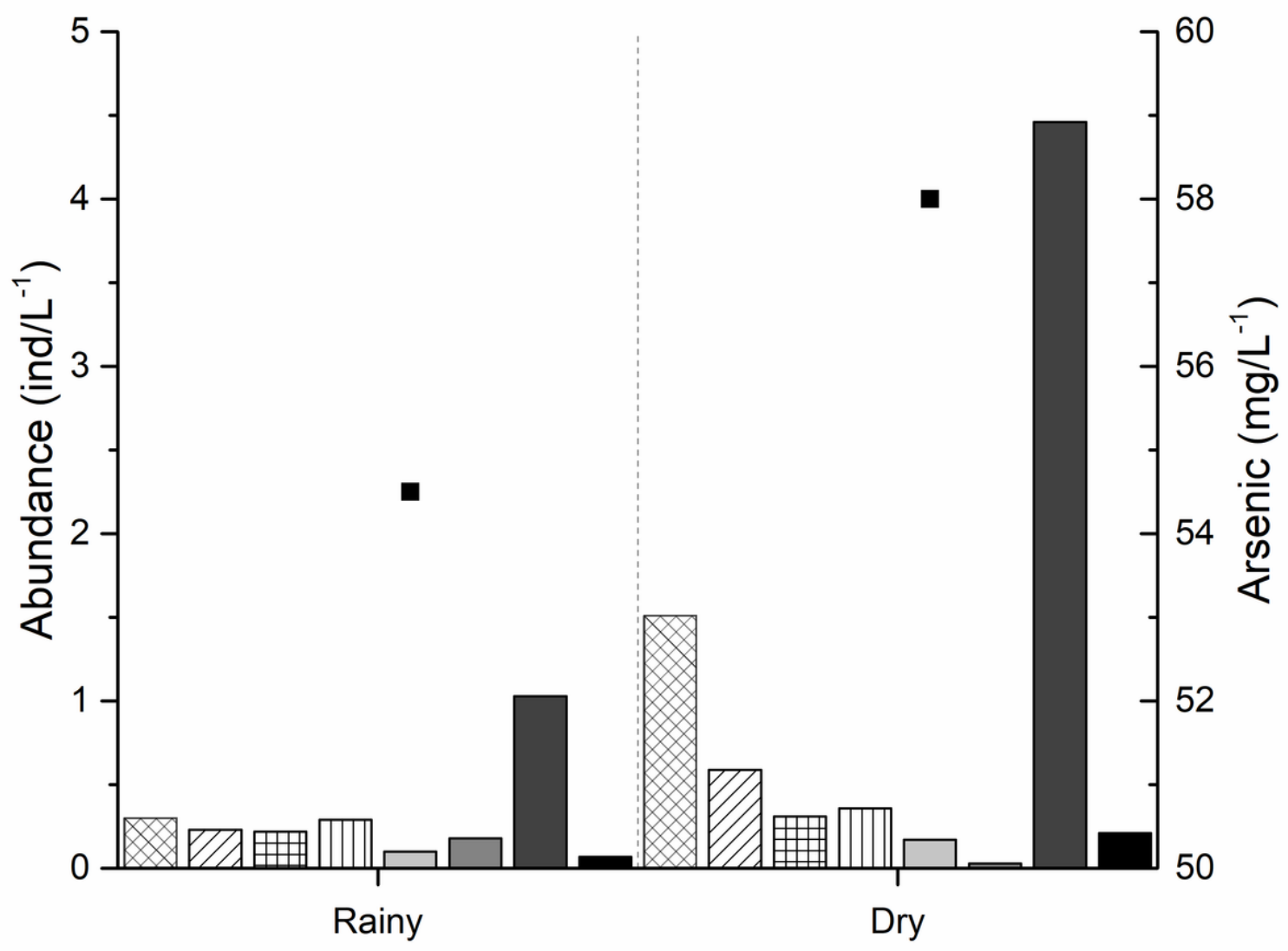

Figure 6

Abundances (ind/L-1) of Paracyclops novenarius (bars) and arsenic concentration (mg/L-1) (squares) in the seasons studied 


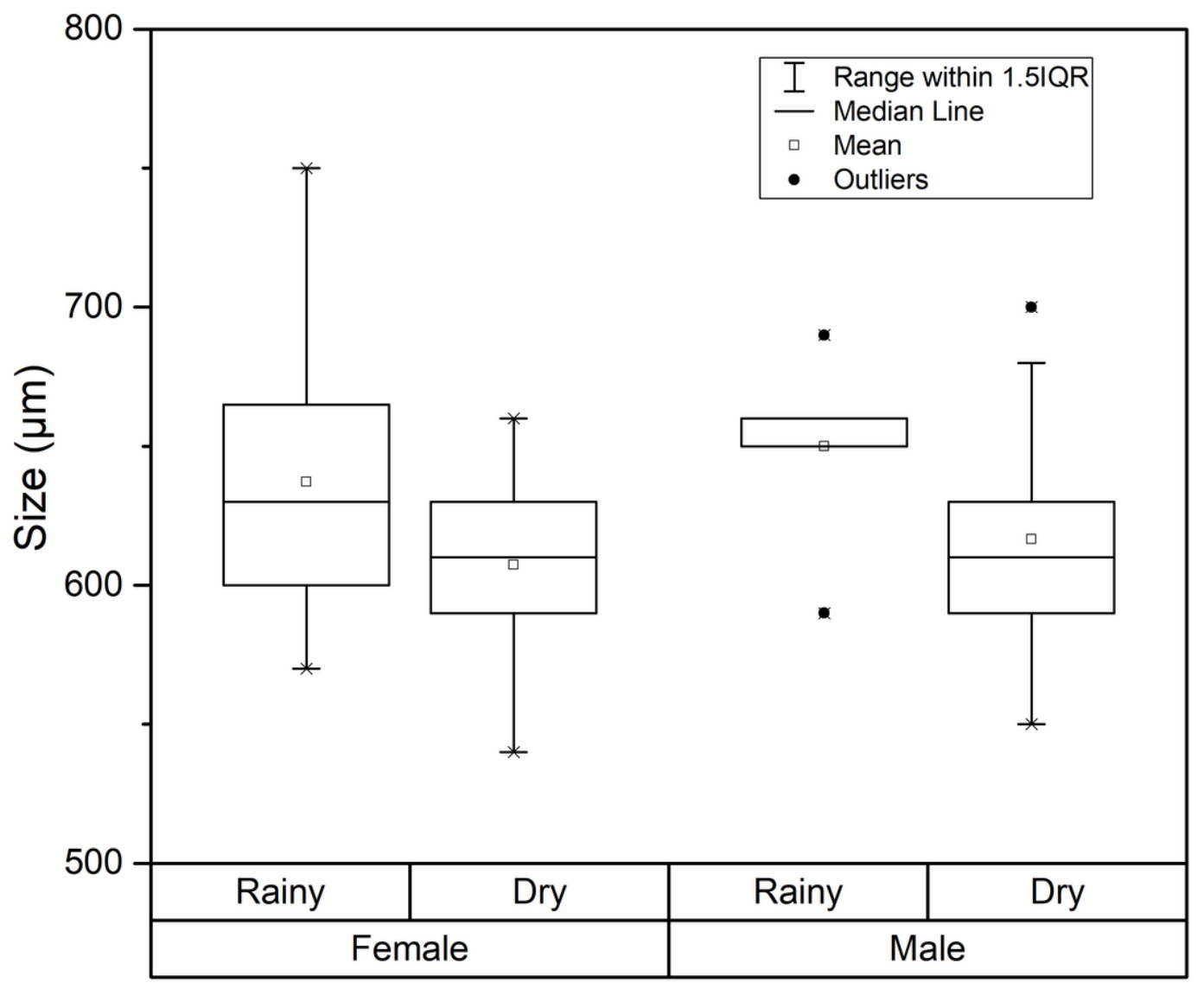

Figure 7

Body size of adult females and males of Paracyclops novenarius in rainy and dry seasons 